Keio J. Med. 21: 255-266, 1972

\title{
REAPPRAISAL OF THYMECTOMY IN HUMAN RENAL ALLOTRANSPLANTATION
}

\author{
HIROSHI NAKAMURA*, HIROSHI YOSHIMATSU**, \\ MASAHARU TSUCHIYA***, NORIKAZU TAMAOKI****, \\ and MOTOAKI ITO*****
}

Department of Urology, Tokyo Electric Power Hospital, Tokyo; Departments of Surgery, Internal Medicine, Pathology and Radiology, School of Medicine, Keio University, Tokyo

(Received for publication September 15, 1972)

Thymectomy has been used in many patients in conjunction with other immunosuppressive agents in Denver, Colorado ${ }^{1-4}$ and in Cleveland, Ohio..$^{5,6}$ Starzl and his associates ${ }^{4}$ evaluated thymectomy as an immunosuppressive measure in a group of 46 patients treated from 4 to $5 \frac{1}{2}$ years ago. Before transplantation the thymus gland was removed transthoracically in 24 randomly selected recipients whose subsequent fates were compared with those of 22 others who dip not have thymectomy. Patients with thymic excision did not have a better survival nor superior renal function, but their allografts tended to have fewer and less severe histopathologic abnormalities when examined long after transplantation.

In Denver, thymectomies were performed through an incision in the second or third left intercostal space. Care was taken to excise the cervical thymic tissue. Yoshimatsu $^{7}$ has approached the thymus through the neck, accomplishing what seemed to be a complete thymectomy in 120 patients. In none of them have there been any surgical complications resulting from thymectomy. Since the technique of thymectomy has been standardized, the thymuses of 5 recipient patients have been transcervically excised, either prior to or after renal allografting for the

* Department of Urology, Tokyo Electric Power Hospital, Tokyo.

** Department of Surgery, School of Medicine, Keio University, Tokyo.

*** Department of Internal Medicine, School of Medicine, Keio University, Tokyo.

**** Department of Pathology, School of Medicine, Keio University, Tokyo.

***** Department of Radiology, School of Medicine, Keio University, Tokyo. 
purpose of reducing the antibody producing tissue of the host.

\section{METHODS}

\section{Clinical studies}

All kidneys were from related donors. Ages of the recipients ranged from 10 to 33 years (Table 1 ). The underlying disease was chronic glomerulonephritis in 2 patients, chronic pyelonephritis in 2 patients, and bilateral renal angiomyolipoma in the third (Table 2). All patients were placed on hemodialysis prior to transplantation. Two patients had splenectomy and bilateral nephrectomy on the day of transplantation. Three patients had a spleen and the diseased kidneys

Table 1

Results with Renal Transplants as of August 15, 1972

\begin{tabular}{|c|c|c|c|c|c|}
\hline Patient & $\underset{\text { (on 8-15-72) }}{\text { Survival }}$ & Rejection & $\begin{array}{l}\text { Renal } \\
\text { function }\end{array}$ & $\begin{array}{l}\text { Genetic relation and age } \\
\text { of donor and recipient }\end{array}$ & $\begin{array}{l}\text { Donor to } \\
\text { recipient } \\
\text { blood } \\
\text { groups }\end{array}$ \\
\hline 1 & 1,342 days & None & Normal & Brother(14) to brother $(10)$ & $O+-A+$ \\
\hline 2 & 771 & $\begin{array}{l}\text { Mild, } 17 \\
\text { days; } \\
\text { reversal }\end{array}$ & Normal & Brother(39) to brother(25) & $\mathrm{B}+-\mathrm{AB}+$ \\
\hline 3 & $246 \prime \prime \prime$ & None & Normal & Brother (26) to brother (31) & $0+-0+$ \\
\hline 4 & $\begin{array}{l}\text { Died } 12 \text { days } \\
\text { of postrenal } \\
\text { failure }\end{array}$ & $\begin{array}{c}\text { None } \\
\text { evident }\end{array}$ & $\begin{array}{l}\text { Improving } \\
\text { before } \\
\text { death }\end{array}$ & Brother (28) to brother(33) & $\mathbf{A}+-\mathbf{A}+$ \\
\hline 5 & $\begin{array}{l}\text { Died } 19 \text { days } \\
\text { of acute } \\
\text { peritonitis }\end{array}$ & $\begin{array}{c}\text { None } \\
\text { evident }\end{array}$ & $\begin{array}{l}\text { Improving } \\
\text { before } \\
\text { death }\end{array}$ & Mother(52) to daughter(25) & $\mathbf{A}+-\mathbf{A}+$ \\
\hline
\end{tabular}

Table 2

Temporal relation to transplantation date of removal of thymus, spleen and kidneys.

\begin{tabular}{|c|c|c|c|c|c|}
\hline \multicolumn{5}{|c|}{ Date of } & \multirow{2}{*}{ Renal disease } \\
\hline \multicolumn{2}{|c|}{ Transplantation } & Thymectomy & Splenectomy & $\begin{array}{c}\text { Bilateral } \\
\text { nephrectomy }\end{array}$ & \\
\hline 1 & $12-12-68$ & 8- 6-71 & $12-12-68$ & $12-12-68$ & Chr. GN \\
\hline 2 & $7-6-70$ & $1-14-71$ & $7-6-70$ & $7-6-70$ & $\prime \prime$ \\
\hline 3 & $12-13-71$ & $11-12-71$ & $11-12-71$ & $5-7-71$ & $\begin{array}{l}\text { Bilateral renal } \\
\text { angiomyolipoma }\end{array}$ \\
\hline 4 & $3-24-72$ & $3-17-72$ & $3-17-72$ & $3-17-72$ & Chr. PN \\
\hline 5 & $5-24-72$ & $1-21-72$ & $1-21-72$ & $1-21-72$ & $" \prime$ \\
\hline
\end{tabular}


removed before transplantation. In 2 patients, thymectomy was performed 967 and $\mathbf{5 5 7}$ days after transplantation. In the other 3 , thymectomy was performed 7 to 124 days before transplantation (Table 2).

Urinalysis, urine culture, complete blood count, blood chemistry, renal function tests, electrophoretic fractions of serum proteins and immunoglobulin were obtained on all patients. Before thymectomy, pneumomediastinography was performed to show the size and shape of the thymus in each patient.

The basic immunosuppressive therapy was azathioprine, prednisolone and local allograft irradiation (Table 3 ). All patients except the first one were also given horse antihuman-lymphocyte globulin injections intramuscularly for the first 3 postoperative months. In 4 patients, prednisolone was started either the day before or on the day of the operation in a dose of $1.0-1.5 \mathrm{mg} / \mathrm{kg}$ per day. The prednisolone dose was then gradually reduced according to the stability of renal function. The second patient first received prednisolone with the threat of rejection (Table 3). As soon as the threat of rejection had passed, the steroid dose was reduced. The total prednisolone doses before thymectomy in the first two patients were 3,120 and $3,498 \mathrm{mg}$.

\section{Technique of thymectomy}

The operative methods for removal of thymuses through the neck (thymectomy via the suprasternal notch) have previously been described. 8 Briefly, thymectomy is carried out with the patient under general endotracheal anesthesia. The patient is placed supine with the sternum elevated. A $3-4 \mathrm{~cm}$ transverse incision is made in the suprasternal notch and deepened through fat, platisma, and the strap muscles. Cervical components of the thymus are exposed just to the deapth of sternothyroid muscles. After identifying the thymus glands, the

\section{Table s}

Non-surgical therapy to prevent rejection

\begin{tabular}{|c|c|c|c|c|}
\hline & Azathioprine & Prednisolone & $\begin{array}{l}\text { Local allograft } \\
\text { irradiation }\end{array}$ & ALG \\
\hline 1 & $\begin{array}{l}\text { Starting on the } \\
\text { day of ope. }\end{array}$ & $\begin{array}{l}\text { Starting the day } \\
\text { before ope. }\end{array}$ & Postop. $300 \mathrm{R}$ & None \\
\hline 2 & $\prime \prime$ & $\begin{array}{l}\text { Starting } 17 \text { th post- } \\
\text { op. days }\end{array}$ & $" 600 \mathrm{R}$ & $\begin{array}{l}\text { Starting 5th preop. } \\
\text { day }\end{array}$ \\
\hline 3 & $\prime \prime$ & $\begin{array}{l}\text { Starting on the } \\
\text { day of ope. }\end{array}$ & " $600 \mathrm{R}$ & $" \prime$ \\
\hline 4 & " & " & None & $"$ \\
\hline 5 & $" \prime$ & $" 1$ & Postop. $150 \mathrm{R}$ & $"$ \\
\hline
\end{tabular}


upper pole of each is easily separable from its surrounding fascial investment, grasped with a clamp and pulled upward, all the time wiping away areolar tissue and fascia with a blunt-tipped aspirator. Traction with serially applied clamps is continuously maintained. The central thymic vein is isolated, doubly ligated and then it is divided. As traction and mobilization proceed, the inferior aspect of each lobe is first felt and then visualized as it is delivered out from under the sternum. A distinct differentiation from the yellow mediastinal fat can be noted at the lower end, assuring complete removal (Fig. 1).

\section{Pathologic studies}

Tissues were obtained from all 5 thymuses at thymectomy. All the tissues were examined by light microscopy. A portion of each specimen was fixed in $10 \%$ formalin and Zenker solution, embedded in paraffin, sectioned, and stained with hematoxylin and eosin, PAS and modified Gomori's silver impregnation.

\section{RESULTS}

\section{Clinical course}

Of the 3 recipients with renal allografts in which thymectomy was carried out prior to transplantation, one remains alive with a well-functioning graft 246 days after transplantation (Table 1 ). The 2 deaths in this group were caused by postrenal failure (12 days) and by acute peritonitis (19 days). However, pathologic studies revealed that the allografts in both patients had no cellular infiltration nor lesions of the vascular, glomerular and fibrotic varieties (Figs. 2 and 3 ).

Two patients in which thymectomy was carried out after renal allotransplantation are alive 1,342 and 771 days after transplantation (Table 1). Both patients have normal renal function.

\section{Pneumomediastinography}

In all patients pneumomediastinogram showed thymic persistence.

\section{Pathologic studies}

Histology of the thymus of patient 1 revealed a well-developed cortex packed with lymphocytes and no sign of replacement by adipose tissue in spite of the prolonged treatment with steroid. There were occasional phagocytes containing nuclear debris in the cortex. Hassall's corpuscles were numerous in the medulla and some of them showed cystic enlargements. The interlobular tissue contained 
a large number of eosinophils (Fig. 4).

The thymus of patient 2 showed a more advanced age involution. The medulla predominated over the cortex which was partially replaced by fatty tissue. A moderate number of phagocytes wih karyorrhexis of lymphocytes were also noted in the cortex. Hassall's corpuscles were small and solid, although some showed marked cystic transformation and calcifications. A few of the small lymphoid follicles lacking germinal centers were found in the medulla. Macrophages filled with a grey, homogeneous substance of undetermined origin were scattered in the perivascular spaces and medulla (Fig. 5).

\section{Urinalysis}

Patient 1 , in whom thymectomy was performed after transplantation, had markedly reduced white blood cells in the urinary sediment after thymectomy. Urinalysis revealed many white blood cells for 5 months before thymectomy. Most cells were lymphocytes and urine cultures yielded no growth. White blood cells, following thymectomy, continued to decrease and fell to $2-3 / \mathrm{HPF}$ after 6 weeks (Fig. 6).

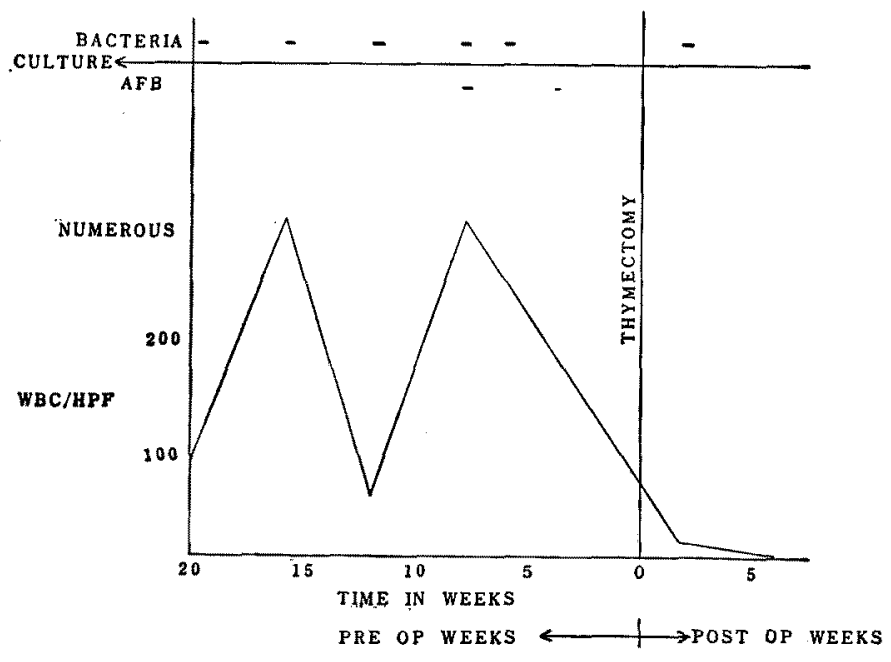

Fig. 6 White blood cells in urinary sediment in patient 1.

\section{Immunoglobulins}

Tables 4 and 5 show the changes of immunoglobulins after thymectomy. 
Table 4

Immunoglobulins before and after thymectomy for two patients in which thymectomy was carried out after renal allotransplantation

\begin{tabular}{c|c|c|c|c|c|c|c|c}
\hline \multirow{2}{*}{ Patient } & \multicolumn{4}{|c|}{ Before thymectomy } & \multicolumn{4}{c}{ After thymectomy } \\
\cline { 2 - 8 } & IgA & $\operatorname{IgG}$ & $\operatorname{IgM}$ & $\beta_{1 \mathrm{C} / \mathrm{A}}$ & $\operatorname{IgA}$ & $\operatorname{IgC}$ & $\operatorname{IgM}$ & $\beta_{\mathbf{1 C} / \mathrm{A}}$ \\
\hline 1 & $\uparrow$ & $\rightarrow$ & $\rightarrow$ & $\downarrow$ & $\uparrow$ & $\rightarrow$ & $\uparrow$ & $\rightarrow$ \\
2 & $\rightarrow$ & $\uparrow$ & $\rightarrow$ & $\rightarrow$ & $\uparrow$ & $\rightarrow$ & $\uparrow$ & $\rightarrow$ \\
\hline
\end{tabular}

$\uparrow$ Higher than normal level

$\rightarrow$ Normal level

$\downarrow$ Lower than normal level

Table 5

Immunoglobulins before and after thymectomy and/or transplantation for three patients in which thymectomy was carried out before renal allotransplantation

\begin{tabular}{|c|c|c|c|c|c|c|c|c|c|c|c|c|}
\hline \multirow{2}{*}{ Patient } & \multicolumn{4}{|c|}{ Before thymectomy } & \multicolumn{4}{|c|}{$\begin{array}{l}\text { Between thymeatomy } \\
\text { and transplantation }\end{array}$} & \multicolumn{4}{|c|}{$\begin{array}{c}\text { After } \\
\text { transplantation }\end{array}$} \\
\hline & $\operatorname{IgA}$ & $\mathrm{IgG}$ & $\operatorname{IgM}$ & $\beta_{1 \mathrm{C} / \mathrm{A}}$ & $\operatorname{IgA}$ & $\operatorname{Ig} G$ & $\lg M$ & $\beta_{1 \mathrm{C} / \mathrm{A}}$ & $\operatorname{Ig} A$ & $\operatorname{IgG}$ & $\operatorname{IgM}$ & $\beta_{1 \mathrm{C} / \mathrm{A}}$ \\
\hline 3 & $\rightarrow$ & $\downarrow$ & $\uparrow$ & $\downarrow$ & $\rightarrow$ & $\downarrow$ & $\uparrow$ & $\rightarrow$ & $\rightarrow$ & $\downarrow$ & $\uparrow$ & $\rightarrow$ \\
\hline 4 & $\downarrow$ & $\downarrow$ & $\uparrow$ & $\downarrow$ & $\downarrow$ & $\rightarrow$ & $\rightarrow$ & $\rightarrow$ & $\downarrow$ & $\rightarrow$ & $\rightarrow$ & $\rightarrow$ \\
\hline 5 & $\downarrow$ & $\downarrow$ & $\uparrow$ & $\downarrow$ & $\downarrow$ & $\downarrow$ & $\rightarrow$ & $\rightarrow$ & $\downarrow$ & $\downarrow$ & $\rightarrow$ & $\rightarrow$ \\
\hline
\end{tabular}

$\uparrow \quad$ Higher than normal level

$\downarrow$ Lower than normal level

$\rightarrow$ Normal level

\section{DISCUSSION}

In both animals and man there is incontrovertible evidence that the thymus at an early stage in life plays a very important part in the development of an immunological response. Mice thymectomized in the immediate neonatal period quickly develop severe depletion in the lymphocyte population and serious impairment of the immune response of the mature animal to Salmonella typhi $\mathrm{H}$ antigen, suffer from progressive wasting and diarrhea, have increased susceptibility to infection, and lose their capacity to react against skin allografts. ${ }^{9-11} \mathrm{~A}$ comparable syndrome of many clinical immunologic deficiencies has been described in children born with extreme deficiencies in the development of the thymus. ${ }^{12}$ In both the foregoing circumstances, thymic function was either never present or was eliminated during the early neonatal period. In contrast, total thymectomy upon normal children did not have these striking immediate effects. ${ }^{13}$ 
In 1962, Miller ${ }^{14}$ demonstrated that an impairment of the ability to recover the capacity for an immune response could follow adult thymectomy under special conditions of testing. Adult mice were provided with skin allografts after a single dose of total body irradiation of $350 \mathrm{r}$. Animals with prior thymectomy retained their transplants for much longer periods than their sham-thymectomized mates. It appeared that complete recovery of the immune mechanism following sublethal irradiation recapitulated some of the events of normal intrauterine and neonatal life in being at least partially thymus-dependent.

Although the value of thymectomy in immunosuppression has not been established, strong theoretical considerations and the possible relationship of the thymus to rejection of allografts make it likely that thymectomy will be employed in addition to chemotherapy in the treatment of patients receiving allografts. Shortly after Starzl's reports, ${ }^{3,4}$ one child and four human adults were subjected to thymectomy at the Tokyo Electric Power Hospital, before and after renal allotransplantation. We do not propose to discuss the effect of thymectomy on renal allotransplantation from the clinical courses of these patients. Suffice it to say that histologic features of the thymus glands removed after transplantation indicate that the thymus might be related to allografts. It has been a matter of universal knowledge that the thymus becomes microscopically atrophic and lacks a recognizable cortex after many months of steroid therapy. In the first two patients, who received 3,120 and $3,498 \mathrm{mg}$ of prednisolone respectively before thymectomy and after transplantation, the gross morphology of both glands was easily distinguishable at operation. Both glands did not lack a cortex. It might be suggested from these findings that the thymus has a possible relationship to the renal allografts by an "autoimmune process" and has not involuted.

With thymectomy in the first patient; there was a progressive change with a secondary fall in the number of lymphocytes in the urinary sediment. The patient had numerous lymphocytes in the urinary sediment for several months before thymectomy. Cultures for bacteria and acid-fast bacilli were repeatedly negative. This might perhaps explain that these lymphocytes appeared to be due primarily to clinically latent rejection and disappeared with thymectomy.

\section{SUMMARY}

The course of 5 patients were studied after renal allotransplantation from related donors. Transcervical thymectomy was performed after transplantation in 2 patients and before transplantation in the other 3 recipients. 
Pathologic studies with light microscopy revealed that the thymuses of patients who received thymectomy after allotransplantation did not lack the cortex even on prednisolone therapy for 557 to 967 days. In the first patient, urinary sediment returned to normal following thymectomy. Patients in terminal renal failure are poor surgical risks but may tolerate the transcervical thymectomy. On theoretic and histopathologic grounds theymectomy will be of value in renal allotransplantation in conjunction with the conventional immunosuppressive treatment.

\section{REFERENCES}

1. Starzl, T. E., Marchioro, T. L., Talmage, D. W., and Waddell, W. R. (1963) Splenectomy and thymectomy in human renal homotransplantation. Proc. Soc. Exp. Biol. Med. 113: 929-932.

2. Starzl, T. E., Marchioro, T. L., Terasaki, P. I., Porter, K. A., Faris, T. D., Herrmann, T. J., Vredevoe, D. L., Hutt, M. P., Ogden, D. A., and Waddell, W. R. (1965) Chronic survival after human renal homotransplantation. Ann. Surg. 162: 749-787.

3. Starzl, T. E., Porter, K. A., Andres, G., Groth, C. G., Putnam, C. W., Penn, I., Halgrimson, C. G., Starkie, S. J., and Brettschneider, L. (1970) Thymectomy and renal homotransplantation. Clin. Exp. Immun. 6: 803-814.

4. Starzl, T. E., Porter, K. A., Andres, G., Halgrimson, C. G., Hurwitz, R., Giles, G., Terasaki, P. I., Penn, I., Schroter, G. T., Lilly, J., Starkie, S. J., and Putnam, C. W. (1970) Long-term survival after renal transplantation in humans: (with special reference to histocompatibility matching, thymectomy, homograft glomerulonephritis, heterologous ALG, and recipient malignancy). Ann. Surg. 172: $437-472$.

5. Crile, G., Jr. (1964) Thymectomy through the neck. Surgery 59: 213-215.

6. Straffon, R. A., Nakamoto, S., and Kolff, W. J. (1965) Clinical experience with renal transplantation. Brit. J. Urol. 37: 370-379.

7. Yoshimatsu, H., Ishihara, T., Kikuchi, K., Ikeda, T., Yamazaki, S., Hatakeyama, T., Murakami, M., Kobayashi, K., Tsuchiya, M., and Shimabukuro, K. (1972) Examination of the thymus and clinical studies in the cases thymectomized via the suprasternal notch. Jap. J. Chest Dis. 31: 194-200. (in Japanese)

8. Yoshimatsu, H., Ikeda, T., Tsuchiya, M., and Shimabukuro, K. (1971) Mediastinoscopy and its application: Thymectomy via the suprasternal notch. Keio J. Med. $20: 29-43$.

9. Miller, J. F. A. P. (1961) Immunological function of the thymus. Lancet 2: 748749 .

10. Miller, J. F. A. P. (1962) Effect of neonatal thymectomy on the immunologic responsiveness of the mouse. Proc. Roy. Soc, Lond. B. 156: 415-428.

11. Martinez, C., Kersey, J. Papermaster, B. W., and Good, R. A. (1962) Skin homograft survival in thymectomized mice. Proc. Soc. Exp. Biol. (N.Y.) 109: 193-196.

12. Good, R. A., Gabrielsen, A. E., Cooper, M. D., and Peterson, R. D. A. (1966) The role of the thymus and bursa of Fabricius in development of effector mechanisms. 
Ann. N.Y. Acad. Sci. 129: $130-154$.

13. Zollinger, R. M., Jr., Lindem, M. C., Filler, R. M., Corson, J. M., and Wilson, R. E. (1964) Effect of thymectomy on skin homograft survival in children. New Engl. J. Med. 270: 707-710.

14. Miller, J. F. A. P. (1962) Imm mological significance of the thymus of the adult mouse. Nature 195: 1318-1319. 


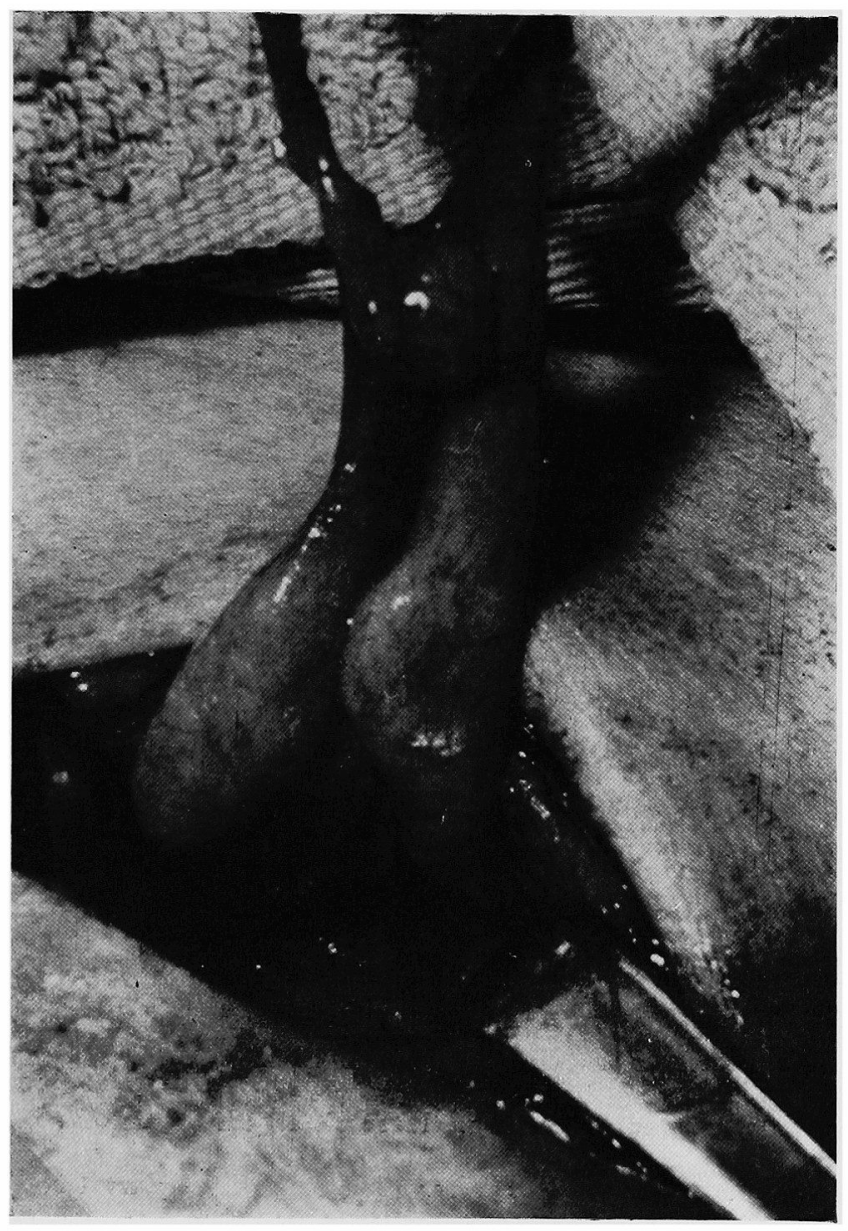

Fig. 1. Thymus being delivered from the mediastinal structures by traction on serially applied clamps. 


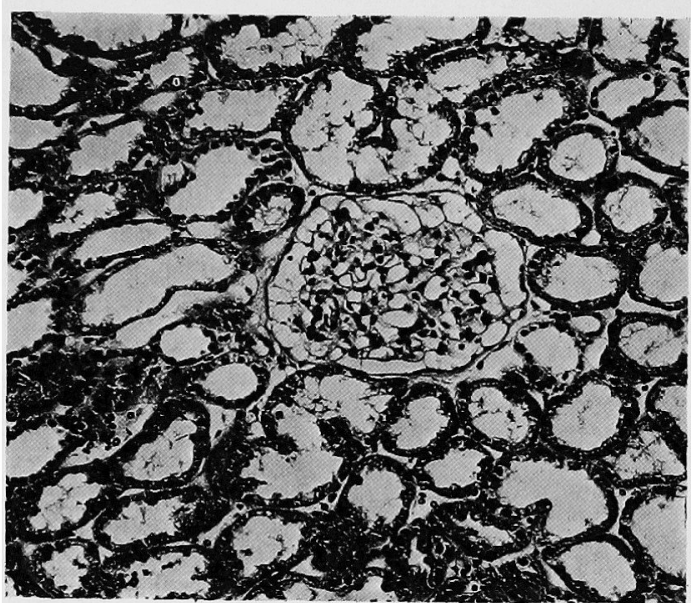

Fig. 2

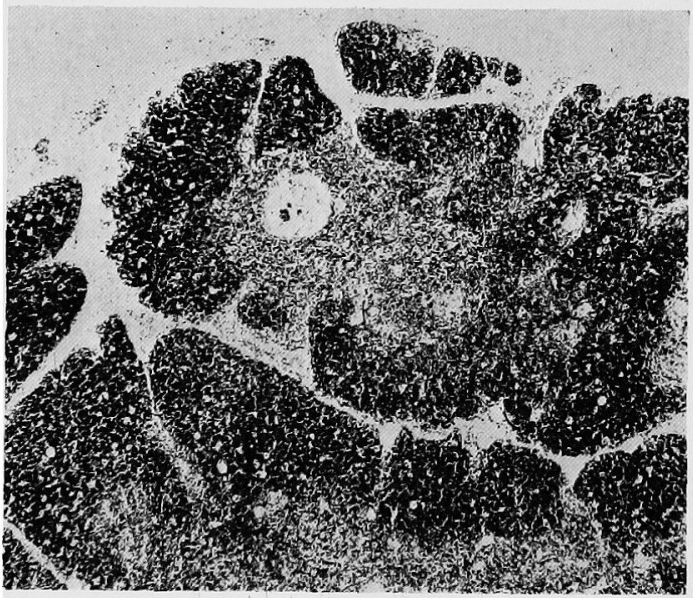

Fig. 4

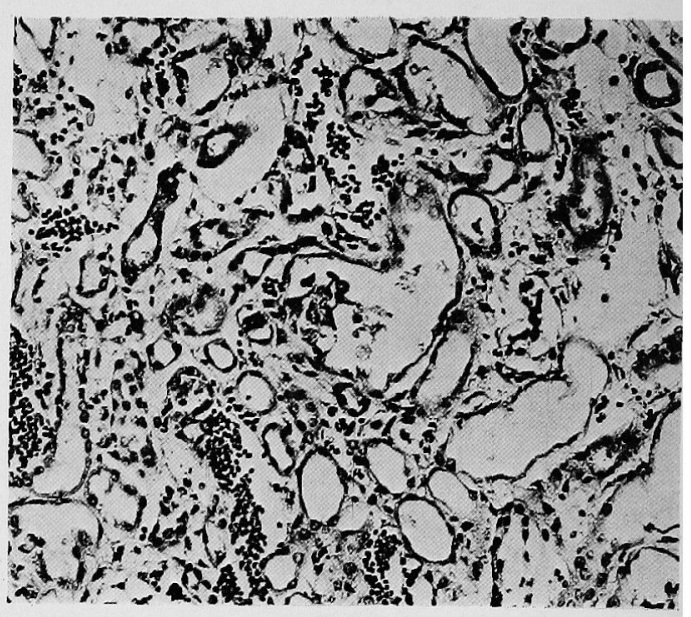

Fig. 3

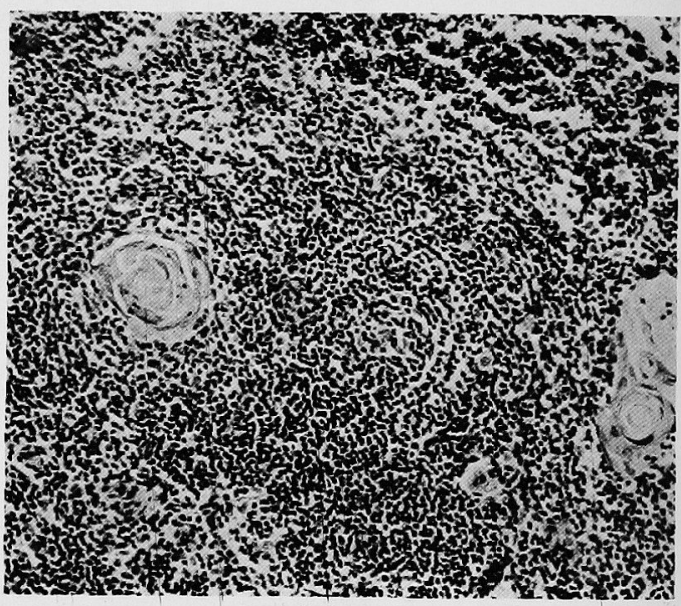

Fig. 5

Fig. 2. A biopsy of transplanted kidney (patient 4) performed on the day of death revealed moderate dilatation of tubules and normal glomeruli. H. \& E. x170.

Fig. 3. Transplanted kidney (patient 5) observed at autopsy. The dilated proximal tubules were covered by flat regenerated epithelium. Interstitial edema was prominent. H. \& E. x170.

Fig. 4. Micrograph of the thymus 967 days after the renal transplantation (patient 1) showing thick cortex with scattered macrophages. H. \& E. $x 40$.

Fig. 5. Micrograph of the thymus 557 days after the renal transplantation (patient 2) showing the follicular structure between two Hassall's corpuscles (center). H. \& E. x170. 